\title{
Prevalence of equine Piroplasmosis and its association with tick infestation in the State of Sáo Paulo, Brazil
}

Prevalência da Piroplasmose equina e sua associação com infestação por carrapatos no Estado de São Paulo

\author{
Claudia E. Kerber ${ }^{1}$; Marcelo B. Labruna ${ }^{2 *}$; Fernando Ferreira ${ }^{2}$; Daniel T. De Waal';
} Donald P. Knowles ${ }^{4}$; Solange M. Gennari ${ }^{2}$

${ }^{1}$ Laboratório Paddock de Análises Clínicas

${ }^{2}$ Departamento de Medicina Veterinária Preventiva e Saúde Animal, Faculdade de Medicina Veterinária e Zootecnia, Universidade de Sáo Paulo - USP

${ }^{3}$ Department of Veterinary Microbiology \& Parasitology, Faculty of Veterinary Medicine, University College Dublin - UCD

${ }^{4}$ Agricultural Research Service, U.S. Department of Agriculture, Washington State University - WSU

Received April 8, 2009

Accepted July 1, 2009

\begin{abstract}
Serum samples were collected from 582 horses from 40 stud farms in the State of São Paulo and tick (Acari: Ixodidae) infestations were evaluated on them. Serum samples were subjected to the complement fixation test (CFT) and a competitive inhibition ELISA (cELISA) for Babesia caballi and Theileria equi. Logistic regression analyses were performed to construct multivariate models that could explain the dependent variable (horses positive for B. caballi or T. equi) as a function of the independent variables (presence or abundance of each one of the tick species found on the farms). A higher overall prevalence of B. caballi (54.1\%) than of T. equi (21.6\%) was found by the two tests. The ticks Dermacentor nitens Neumann, 1897, Amblyomma cajennense (Fabricius, 1787) and Rhipicephalus (Boophilus) microplus (Canestrini, 1887) were present on horses on 38 (95\%), 20 (50\%), and 4 (10\%) farms, respectively. Infestations by $D$. nitens were statistically associated with $B$. caballi-positive horses on the farms by either the CFT or cELISA. Infestations by $A$. cajennense were statistically associated with T. equi-positive horses on the farms by either CFT or cELISA.
\end{abstract}

Keywords: Babesia caballi, Theileria equi, Brazil, horse, tick.

\section{Resumo}

Amostras de soro sanguineo foram coletadas de 582 equinos de 40 haras no estado de São Paulo, onde as infestaçôes por carrapatos foram avaliadas nos animais. Os soros foram testados por reação de fixação do complemento (RFC) e ELISA competitivo por inibição (cELISA) com antígenos de Babesia caballi e Theileria equi. Análises de regressão logística foram realizadas para construir modelos multivariados que pudessem explicar as variáveis dependentes (equinos positivos para $B$. caballi ou T. equi) em função de variáveis independentes (presença e abundância de cada uma das espécies de carrapatos encontradas nos equinos dos haras). Em geral, os dois testes sorológicos indicaram uma prevalência maior para B. caballi $(54,1 \%)$ do que para T. equi (21,6\%). Os carrapatos Dermacentor nitens Neumann, 1897, Amblyomma cajennense (Fabricius, 1787) e Rhipicephalus (Boophilus) microplus (Canestrini, 1887) estiveram presentes em equinos de 38 (95\%), 20 (50\%) e 4 (10\%) haras, respectivamente. As infestaçóes por D. nitens estiveram estatisticamente associadas com equinos positivos para B. caballi tanto pela RFC como pelo cELISA. As infestaçóes por A. cajennense estiveram estatisticamente associadas com equinos soropositivos para T. equi, tanto pela RFC como pelo cELISA.

Palavras-chave: Babesia caballi, Theileria equi, Brasil, cavalo, carrapato.

\footnotetext{
${ }^{*}$ Corresponding author: Marcelo Bahia Labruna

Departamento de Medicina Veterinária Preventiva e Saúde Animal,

Faculdade de Medicina Veterinária e Zootecnia, Universidade de São Paulo - USP,

Av. Prof. Dr. Orlando Marques de Paiva, 87, CEP 05508-270 Cidade Universitária,

São Paulo - SP, Brasil; e-mail: labruna@usp.br

Supported by: FAPESP (grant \# 98/15698-1 to Gennari, S.M.)
} 


\section{Introduction}

Equine piroplasmosis is a protozoan disease caused by two agents in Brazil: Babesia caballi and Theileria equi (BARBOSA et. al., 1995; HEUCHERT et al., 1999; KERBER et al., 1999, CANOLA et al., 2007; HEIM et al. 2007; BALDANI et al., 2008). The severity of clinical signs is variable, and in many cases spontaneous recovery may occur without obvious clinical signs. This is especially true in endemic areas where foals become infected while they are protected by maternal antibodies and other non-specific factors, which render them partially resistant to challenge (RIBEIRO et al.,1995). Maternal antibodies are usually undetectable 3 to 5 months after birth (ALLSOPP et al., 2007; KUMAR et al., 2008). Therefore, foals undergo a non-apparent infection but there is some evidence that stress factors may lead to relapsing clinical episodes later in life (DE WAAL, 1995; FRIEDHOFF, 1988).

Equine piroplasmosis is an important disease of equids and it has a specific impact on international trade. Horses infected with equine piroplasmosis remain carriers for long periods and act as source of infection for ticks. Theileria equi can also be transmitted iatrogenically by the reuse of needles (TENTER; FRIEDHOFF, 1986;). Stress, such as after intensive training or transport, may lead to recrudescent parasitaemia in carrier animals, influencing the performance of sporting horses. Reproductive failure of mares, as a result of intra-uterine infection of the fetus, particularly with T. equi, is quite common in some countries (CORREA et al., 1978; DE WAAL, 1995). Elimination of T. equi infections by chemotherapy is unsatisfactory. To prevent the introduction into disease-free countries, very strict international import and export regulations are applied and movement of horses is only permitted if they are deemed to be free of infection, i.e., a negative result on the indirect immunofluorescence assay (IFA) or enzyme-linked immunosorbent assay (ELISA) (OFFICE INTERNATIONAL DES EPIZOOTIES, 2005). Until the beginning of this decade, the complement fixation test (CFT) was also accepted for international trade of horses (USDA, 1997; DE WAAL, 2000). Nowadays, this test is still widely used for other purposes (OGUNREMI et al., 2007).

Serological studies concerning infection by B. caballi and T. equi have shown that these two agents are widely distributed in Brazil, with herd prevalence ranging from 1.4 to $100 \%$ (BARBOSA et al., 1995; BITTENCOURT et al., 1997; KERBER et al., 1999; RIBEIRO et al., 1999; XUAN et al., 2001; BOTTEON et al., 2002; BALDANI et al., 2004; 2007; COSTA PEREIRA et al., 2005; HEIM et al., 2007). These values have been shown to be affected by climatic conditions and farm management.

Studies have shown that three major tick species infest horses in Brazil: Dermacentor nitens (= Anocentor nitens), Amblyomma cajennense, and Rhipicephalus (Boophilus) microplus (FALCE, 1986; BARBOSA et al., 1995; HEUCHERT et al., 1999; LABRUNA et al., 2001; COSTA PEREIRA et al., 2005). Although horses are considered primary hosts for $D$. nitens and $A$. cajennense, they are not so for $R$. (B.) microplus, as their infestation by this tick is dependent on the presence of cattle grazing with horses in the same pasture (LABRUNA et al., 2001). On the American continent, $D$. nitens is the only known vector of
B. caballi (ROBY; ANTHONY, 1963) and in Brazil the prevalence of $B$. caballi mainly coincides with the distribution of this tick. Although T. equi is transmitted by different two- and three-host ticks in the Old World (FRIEDHOFF, 1988), information on natural tick vectors is still limited in the New World (STILLER; COAN, 1995). Dennig (1988) was unsuccessful in infecting $A$. cajennense and $D$. nitens with $T$. equi. On the other hand, the vector competence of $R$. (B.) microplus has been repeatedly demonstrated, with successful transestadial and intrastadial survival of T. equi in this tick (GUIMARÃES et al., 1998; STILLER et al., 2002; UETI et al., 2005; 2008). In fact, T. equi-infected horses have been reported in areas where $R$. (B.) microplus is the only tick found parasitizing horses, especially in southern Brazil (SOUZA et al., 2000). Rhipicephalus. (B.) microplus is a onehost tick and the epidemiological significance of this tick vector remains under discussion, especially for highly endemic areas, since it is accepted that there is no transovarial transmission of T. equi in ticks.

Studies on risk factors could support the adoption of specific measures that would minimize the introduction or dispersion of the disease among farms. Moreover, such studies could indicate epidemiological evidence about the mechanisms by which the agent disseminates in the host population. Thus, the present work was conducted with the purpose of evaluating the prevalence of equine piroplasmosis and possible associations between ticks infesting horses and the presence of serologically positive horses in the State of São Paulo, with emphasis on T. equi.

\section{Material and Methods}

\section{Farms}

From December 1998 to March 1999, 40 stud farms were studied in the state of São Paulo, southeastern Brazil. The farm localities and number of farms per locality have been illustrated elsewhere (LABRUNA et al., 2001). All farms had horse breeding as the major livestock activity and the equine breeds among the 40 farms included Thoroughbred (8 farms), Quarter Horse (7), Mangalarga Paulista (5), Mangalarga Marchador (4), Andaluzian (4), Lusitanian (4), Brasileiro de Hipismo (4), Arabian (3), and Morgan (1).

\section{Farm visits}

During visits to farms, blood samples were obtained in siliconized vacutainer tubes from all horses 6-24 months old, reared under grazing conditions. If any of these horses had left the farms for any reason during their lives, or if any of them had received a blood transfusion or plasma therapy at any stage, they were excluded from the serological analysis. This age group was selected because older animals generally had already left the farm area for various purposes. The serological status of the 6-24 months old horses therefore exclusively reflects the epidemiological conditions particular to each farm. Blood samples were centrifuged and the 
serum from each sample was decanted into separate containers in the laboratory. The containers were then stored and maintained at $-20^{\circ} \mathrm{C}$ until processed.

During visits to farms, tick infestations were evaluated on the horses, especially among the 6-24 month age group. Details of the presence and abundance of the ticks $D$. nitens, $A$. cajennense, and $R$. (B.) microplus infesting the horses of these 40 farms have been published elsewhere (LABRUNA et al., 2001). If any of these tick species were not found on the target age group (6-24 months old), older horses were also examined. The occurrence of each tick species was categorized qualitatively per farm as follows: level zero: no ticks on the horses; low-level infestation: mean of less than 10 adult ticks per horse; high-level infestation: mean of more than 10 adult ticks per horse (LABRUNA et al., 2001). Animals that had been recently treated with acaricides were not included in these assessments. Adult ticks were only considered for this analysis because farms were visited during the summer, when adults of $A$. cajennense are in their highest peak of abundance (LABRUNA et al., 2002). For D. nitens and $R$. (B.) microplus, both one-host ticks, adults are found throughout the year, but also with major peaks encompassing summer months (LABRUNA et al., 2002; CAMPOS PEREIRA et al., 2008).

On each farm visit a questionnaire was served to the farm supervisor with the purpose of gaining information about horse management, especially of the historical usage of discarded needles on the horses for any therapeutic purpose and the presence of horse fly (Tabanidae) infestations on the horses.

\section{Serological testing}

All serum samples were subjected to the CFT and a competition inhibition ELISA (cELISA) test for B. caballi and T. equi. The CFT test was performed following the protocol of the United States Department of Agriculture (USDA, 1997), which also supplied the reagents. Trace, $1+$ to $4+$ was considered as positive reactions in a 1:5 dilution. The cELISA test was performed as described elsewhere (KNOWLES et al., 1991; 1992; KAPPMEYER et al., 1999). Both serologic tests were performed with USDA standardized antigens and reagents, which have been regularly supplied by USDA to the Laboratório Paddock de Análises Clínicas, São Paulo, Brazil, where serologic tests were performed for the present study, under C. E. Kerber.

\section{Statistical analysis}

The proportions of horses in the 6-month to 24-month age group that were serologically positive for B. caballi and T. equi were calculated separately for each farm, for each one of the serological assays (CFT and cELISA). For data analysis, a logistic regression was performed to construct multivariate models that could explain the dependent variable (horses serologically positive for B. caballi or T. equi) as a function of the independent variables (presence and abundance of each one of the tick species found on the farms). For this purpose, infestations of horses by $D$. nitens, $A$. cajennense or $R$. (B.) microplus were analyzed qualitatively at a dichotomous level (absence $=0$; presence $=1$ ) or at a semi-quantitatively dichotomous level (level zero and low level of infestation $=0$; high level of infestation $=1$ ). The serological results of each farm were analyzed at two separate dichotomous levels: firstly, with the presence or absence of positive horses (no positive horse $=0$; at least one positive horse on the farm =1) and secondly, at the proportion of positive horses on the farm (less than $30 \%$ of horses positive $=0$; more than $30 \%$ of horses positive $=1$ ). A separate statistical analysis was performed for each serological test (CFT and cELISA).

The independent variables were subjected to univariate analysis and those with statistical association (here considered as $\mathrm{P}<0.20$, $\chi^{2}$ test, for this first analysis) were tested in the multivariate model by the stepwise forward method. The variables were included in the multivariate model if they displayed statistical significance of $\mathrm{P}<0.05$, considering also the significance level of the final model. In the case of T. equi, the probability values of horses to be infected by this agent were calculated, considering the significant independent variables indicated by the multivariate analysis. A Kappa coefficient was calculated for the serological results shown by CFT and cELISA among all sera samples. All analyses were performed using SPSS for Windows (1999).

\section{Results}

\section{Overall serologic results}

A total of 582 sera samples were obtained from horses on the 40 farms (mean: $14.55 \pm 11.98$ horses per farm, range: $4-60$ ) and tested by CFT and cELISA. The results of these tests are given in Table 1. There was an overall higher prevalence of B. caballi $(54.1 \%)$ than of T. equi $(21.6 \%)$ infected horses. There were discrepancies between the CFT and cELISA results, with the cELISA detecting more positive and less negative $B$. caballi horses than the CFT, while, quite unexpectedly, the opposite was true for T. equi. The Kappa coefficients between the two tests were 0.67 for B. caballi and 0.70 for T. equi, indicating a substantial agreement between the CFT and cELISA (THRUSFIELD, 1995).

Comparing the two serological tests, 31 and 32 farms had at least one positive horse for $B$. caballi by CFT and cELISA, respectively, and 24 and 23 farms had at least one positive horse for T. equi by CFT and cELISA, respectively (Table 2 ). Considering the level of infection on the farms, 26 and 31 farms showed more than $30 \%$ of horses positive for B. caballi by CFT and cELISA, respectively, and 11 and 12 farms showed more than $30 \%$ of horses positive for T. equi by CFT and cELISA, respectively.

\section{Ticks}

Three tick species were found on the horses during the study (Table 2). The most common species, D. nitens, was present on 38 farms (95\%), with 22 farms (55\%) showing high-level infestations. Amblyomma cajennense was present on 20 farms (50\%), with 8 farms (20\%) showing high infestations on horses. The third species, $R$. (B.) microplus, was present on horses from 
Table 1. Comparison of serologic tests of 582 serum samples from 6 to 24-month-old horses from São Paulo, Brazil.

\section{Test results}

\begin{tabular}{lcc}
\multicolumn{1}{c}{ Test results } & Babesia caballi & Theileria equi \\
\cline { 2 - 3 } & $318(54.6)$ & $166(28.5)$ \\
Positive by CFT & $405(69.6)$ & $155(26.6)$ \\
Positive by cELISA & $315(54.1)$ & $126(21.6)$ \\
Positive by both tests & $264(45.4)$ & $416(71.5)$ \\
Negative by CFT & $177(30.4)$ & $427(73.4)$ \\
Negative by cELISA & $174(29.9)$ & $387(66.5)$ \\
Negative by both tests & $3(0.5)$ & $40(6.9)$ \\
Positive by CFT, negative by cELISA & $90(15.5)$ & $29(5.0)$ \\
Negative by CFT, positive by cELISA & & \\
\hline
\end{tabular}

No of reactive serum samples (\% positive)

$155(26.6)$

$126(21.6)$

$387(66.5)$

$29(5.0)$

$\mathrm{No}^{\mathrm{N}}=$ number

Table 2. Serological tests for Babesia caballi and Theileria equi of horses from 40 stud farms, according to the tick species found on horses on the farms.

\begin{tabular}{|c|c|c|c|c|c|c|c|c|c|}
\hline \multirow[t]{2}{*}{$\begin{array}{l}\text { Tick species found } \\
\text { on at least one } \\
\text { horse on the farm }\end{array}$} & \multirow[t]{2}{*}{$\begin{array}{l}\text { No of } \\
\text { farms }\end{array}$} & \multicolumn{2}{|c|}{$\begin{array}{c}\text { No of farms with at least } \\
\text { one horse positive } \\
\text { for } B \text {. caballi } \\
(\%)\end{array}$} & \multicolumn{2}{|c|}{$\begin{array}{c}\text { No of farms with at least } \\
\text { one horse positive } \\
\text { for } T \text {. equi } \\
(\%)\end{array}$} & \multicolumn{2}{|c|}{$\begin{array}{c}\mathrm{No}^{\circ} \text { of farms with more } \\
\text { than } 30 \% \text { of horses } \\
\text { positive for B. caballi } \\
(\%)\end{array}$} & \multicolumn{2}{|c|}{$\begin{array}{c}\text { No of farms with more } \\
\text { than } 30 \% \text { of horses } \\
\text { positive for } T \text {. equi } \\
(\%)\end{array}$} \\
\hline & & CFT & cELISA & CFT & cELISA & CFT & cELISA & CFT & cELISA \\
\hline A & 15 & $14(93.3)$ & $15(100)$ & $9(60)$ & 7 (46.6) & $11(73.3)$ & $14(93.3)$ & $1(6.6)$ & $2(13.3)$ \\
\hline$A$ and $B$ & 19 & $13(68.4)$ & $13(68.4)$ & $12(63.1)$ & $13(68.4)$ & $11(57.8)$ & $13(68.4)$ & $8(42.1)$ & $8(42.1)$ \\
\hline$A$ and $C$ & 3 & $3(100)$ & $3(100)$ & $2(66.6)$ & $2(66.6)$ & $3(100)$ & $3(100)$ & $1(33.3)$ & $1(33.3)$ \\
\hline $\mathrm{A}, \mathrm{B}$, and $\mathrm{C}$ & 1 & $1(100)$ & $1(100)$ & $1(100)$ & $1(100)$ & $1(100)$ & $1(100)$ & $1(100)$ & $1(100)$ \\
\hline no ticks & 2 & $0(0)$ & $0(0)$ & $0(0)$ & $0(0)$ & $0(0)$ & $0(0)$ & $0(0)$ & $0(0)$ \\
\hline Total & 40 & $31(77.5)$ & $32(80)$ & $24(60)$ & $23(57.5)$ & $26(65)$ & $31(77.5)$ & $11(27.5)$ & $12(30)$ \\
\hline
\end{tabular}

${ }^{a} \mathrm{~A}$ : Dermacentor nitens; B: Amblyomma cajennense; C: Rhipicephalus (Boophilus) microplus. $\mathrm{N}^{\circ}=$ number.

only 4 farms (10\%), of which 2 had high infestations. Only 2 farms were completely free of tick infestation on horses. All the farms that had $A$. cajennense or $R$. (B.) microplus infestations also had $D$. nitens infestations. Only 1 of the 4 farms with $R$. (B.) microplus infestations on horses also had $A$. cajennense infestations. Table 2 and 3 summarize the serological status of the farms in respect to the tick species found on the horses.

All farms reported using only sterile disposable needles for treatment of horses and always discarding needles after use. All farms also reported infestations by horse flies (presumably Tabanidae) on horses every year, with high fly burdens occurring during the spring-summer months.

\section{Babesia caballi}

Both the CFT and the cELISA results gave similar statistical associations when compared to the independent variables related to tick species found on horses on the farms (Table 4). By the univariate analysis, the presence of at least one serologically positive horse for B. caballi by CFT was statistically coupled $(\mathrm{P}<0.20)$ with both the presence and the high-level infestation of $D$. nitens on the horses. However, when these two independent variables were subjected to the multivariate analysis, the presence of $D$. nitens was excluded and only its high level of infestation (mean infestation of more than 10 adult ticks per horse) was statistically associated with the presence of at least one horse positive for B. caballi on CFT (model significance $P=0.0001$ ). Identical significant associations were observed when the presence of at least one horse serologically positive for $B$. caballi by cELISA on the farm was compared to the independent variables (Table 4).

Similarly, the univariate analysis indicated that the presence of more than $30 \%$ of horses on the farm positive for B. caballi, by either CFT or cELISA, was also statistically coupled $(\mathrm{P}<0.20)$ with the presence and with high-level infestation by $D$. nitens on the horses. Again, when these two independent variables were subjected to the multivariate analysis, only the high-level infestation by $D$. nitens was statistically associated with more than $30 \%$ of horses positive for $B$. caballi on the farm, by either CFT or cELISA. Both models (one for each serological test) were highly significant $(\mathrm{P}=0.0001)$.

\section{Theileria equi}

By the univariate analysis, the presence of at least one horse serologically positive for T. equi by CFT was statistically coupled $(\mathrm{P}<0.20)$ with three variables: the presence of $D$. nitens, high-level infestation by $D$. nitens, and high-level infestation by $A$. cajennense on the horses. The cELISA results indicated that the above three variables and a fourth, the presence of $A$. cajennense on the horses, were significant in the univariate analysis $(\mathrm{P}<0.20)$. However, when 
Table 3. Serological tests on horses from 25 stud farms which had high infestation levels by ticks on the horses.

\begin{tabular}{|c|c|c|c|c|c|c|c|c|c|}
\hline \multirow[t]{2}{*}{$\begin{array}{l}\text { Tick species found } \\
\text { at high infestation } \\
\text { level on the horses }\end{array}$} & \multirow[t]{2}{*}{$\begin{array}{l}\text { No of } \\
\text { farms }\end{array}$} & \multicolumn{2}{|c|}{$\begin{array}{c}\text { No of farms with at least } \\
\text { one horse positive } \\
\text { for } B \text {. caballi } \\
(\%)\end{array}$} & \multicolumn{2}{|c|}{$\begin{array}{c}\text { No of farms with at least } \\
\text { one horse positive } \\
\text { for } T \text {. equi } \\
(\%)\end{array}$} & \multicolumn{2}{|c|}{$\begin{array}{c}\mathrm{N}^{\circ} \text { of farms with more } \\
\text { than } 30 \% \text { of horses } \\
\text { positive for } B \text {. caballi } \\
(\%)\end{array}$} & \multicolumn{2}{|c|}{$\begin{array}{c}\text { No of farms with more } \\
\text { than } 30 \% \text { of horses } \\
\text { positive for T. equi } \\
(\%)\end{array}$} \\
\hline & & CFT & cELISA & CFT & cELISA & CFT & cELISA & CFT & cELISA \\
\hline A & 16 & $16(100)$ & $16(100)$ & $13(81.2)$ & $10(62.5)$ & $16(100)$ & $16(100)$ & $2(12.5)$ & $3(18.7)$ \\
\hline B & 3 & $2(66.6)$ & $2(66.6)$ & $3(100)$ & $3(100)$ & $1(33.3)$ & $2(66.6)$ & $3(100)$ & $2(66.6)$ \\
\hline$A$ and $B$ & 4 & $4(100)$ & $4(100)$ & $4(100)$ & $4(100)$ & $4(100)$ & $4(100)$ & $4(100)$ & $4(100)$ \\
\hline$A$ and $C$ & 1 & $1(100)$ & $1(100)$ & $1(100)$ & $1(100)$ & $1(100)$ & $1(100)$ & $1(100)$ & $1(100)$ \\
\hline $\mathrm{A}, \mathrm{B}$, and $\mathrm{C}$ & 1 & $1(100)$ & $1(100)$ & $1(100)$ & $1(100)$ & $1(100)$ & $1(100)$ & $1(100)$ & $1(100)$ \\
\hline Total & 25 & $24(96)$ & $24(96)$ & $22(88)$ & $19(76)$ & $23(92)$ & $24(96)$ & $11(44)$ & $11(44)$ \\
\hline
\end{tabular}

${ }^{2}$ A: Dermacentor nitens; B: Amblyomma cajennense; C: Rhipicephalus (Boophilus) microplus. № = number.

Table 4. Results of statistical analysis between the presence of tick species found on the horses and the horse serological status on the farm for Babesia caballi or Theileria equi by CFT or cELISA.

\begin{tabular}{|c|c|c|c|c|c|c|c|c|}
\hline \multirow[b]{3}{*}{$\begin{array}{c}\text { Tick species on the } \\
\text { horses }\end{array}$} & \multicolumn{8}{|c|}{ P-values of univariate analysis for serologically positive horses by: } \\
\hline & \multicolumn{4}{|c|}{ CFT } & \multicolumn{4}{|c|}{ cELISA } \\
\hline & $\begin{array}{c}\text { At least } \\
\text { one horse } \\
\text { positive for } \\
\text { B. caballi }\end{array}$ & $\begin{array}{c}\text { At least } \\
\text { one horse } \\
\text { positive for } \\
T . \text { equi }\end{array}$ & $\begin{array}{c}\text { More than } \\
30 \% \text { of horses } \\
\text { positive for } \\
\text { B. caballi }\end{array}$ & $\begin{array}{c}\text { More than } \\
30 \% \text { of horses } \\
\text { positive for } \\
\text { T. equi }\end{array}$ & $\begin{array}{c}\text { At least } \\
\text { one horse } \\
\text { positive for } \\
\text { B. caballi }\end{array}$ & $\begin{array}{c}\text { At least } \\
\text { one horse } \\
\text { positive for } \\
\text { T. equi }\end{array}$ & $\begin{array}{c}\text { More than } \\
30 \% \text { of horses } \\
\text { positive for } \\
\text { B. caballi }\end{array}$ & $\begin{array}{c}\text { More than } \\
30 \% \text { of horses } \\
\text { positive for } \\
T . \text { equi }\end{array}$ \\
\hline $\begin{array}{l}\text { Presence of } \\
\text { D. nitens }\end{array}$ & $0.121^{\mathrm{a}}$ & $0.057^{\mathrm{a}}$ & $0.037^{\mathrm{a}}$ & 0.548 & $0.096^{\mathrm{a}}$ & $0.069^{\mathrm{a}}$ & $0.009^{a}$ & 0.541 \\
\hline $\begin{array}{l}\text { Presence of } \\
\text { A. cajennense }\end{array}$ & 0.712 & 0.301 & 0.816 & $0.007^{\mathrm{a}}$ & 0.442 & $0.184^{\mathrm{a}}$ & 0.712 & $0.023^{\mathrm{a}}$ \\
\hline $\begin{array}{c}\text { Presence of } \\
R .(B .) \text { microplus }\end{array}$ & 0.557 & 0.638 & 0.278 & 0.300 & 0.566 & 0.624 & 0.557 & 0.570 \\
\hline $\begin{array}{l}\text { High level infestation } \\
\text { by } D \text {. nitens }\end{array}$ & $<0.001^{\mathrm{a}, \mathrm{b}}$ & $<0.001^{\mathrm{a}, \mathrm{b}}$ & $<0.001^{\mathrm{a}, \mathrm{b}}$ & 0.286 & $0.001^{\mathrm{a}, \mathrm{b}}$ & $0.031^{\mathrm{a}, \mathrm{b}}$ & $<0.001^{\mathrm{a}, \mathrm{b}}$ & $0.096^{\mathrm{a}}$ \\
\hline $\begin{array}{l}\text { High level infestation } \\
\text { by } A \text {. cajennense }\end{array}$ & 0.655 & $0.013^{\mathrm{a}, \mathrm{b}}$ & 0.689 & $<0.001^{\mathrm{a}, \mathrm{b}}$ & 1.000 & $0.013^{\mathrm{a}, \mathrm{b}}$ & 0.655 & $<0.001^{\mathrm{a}, \mathrm{b}}$ \\
\hline
\end{tabular}

${ }^{a}$ Significantly at the univariate analysis $(\mathrm{P}<0.20)$. ${ }^{\mathrm{b}}$ Included in the final multivariate model (model significance $\left.\mathrm{P}<0.05\right)$.

all these independent variables were submitted to the multivariate analysis with either CFT or cELISA results, only the high level of infestation by $D$. nitens or $A$. cajennense were statistically associated with the presence of at least one horse positive for T. equi on the farm. Both models (one for each serological test) were highly significant $(\mathrm{P}<0.001)$.

The univariate analysis indicated that the presence of more than $30 \%$ of horses positive for T. equi on the farm by CFT was statistically coupled $(\mathrm{P}<0.20)$ with two variables: the presence of $A$. cajennense, and its high-level infestation on horses. In comparison, the cELISA results showed that with more than $30 \%$ of T. equi-positive horses on the farm, the above two variables and a third, high level of infestation by $D$. nitens on the horses, were significant in the univariate analysis $(\mathrm{P}<0.20)$. However, when these independent variables were submitted to the multivariate analysis, only the high-level infestation by $A$. cajennense was statistically associated with more than $30 \%$ of horses positive for T. equi on the farm by either CFT or cELISA (both model significances were $P=0.0001)$. The presence of $R$. (B.) microplus on the horses on the farms was not statistically associated $(\mathrm{P}>0.20)$ with any of the serological results (Table 4).

Probability values for farms to have more than $30 \%$ of horses serologically positive for T. equi were calculated. Using the CFT data, the probability that a farm with low-level infestation by A. cajennense would have more than $30 \%$ of horses positive for T. equi was $9.4 \%$. If the farm had a high level of infestation by A. cajennense on the horses, this probability increases to $99.9 \%$. Similarly, using the cELISA data, the probability that a farm with low-level infestation by $A$. cajennense would have more than $30 \%$ of horses positive for $T$. equi was $15.6 \%$, whereas with a highlevel infestation by $A$. cajennense on the horses, this probability increased to $87.5 \%$.

\section{Discussion}

The present study reinforces previous studies that showed horse piroplasmosis to be endemic in Brazil (BARBOSA et al., 1995; BITTENCOURT et al., 1997; KERBER et al., 1999; 
RIBEIRO et al., 1999; XUAN et al., 2001; BOTTEON et al., 2002; BALDANI et al. 2007; HEIM et al. 2007). In addition, it highlights the epidemiological associations between tick infestations and serologically positive results for $B$. caballi and T. equi in horses. The significant association $(\mathrm{P}<0.05)$ between the high-level infestation by $D$. nitens on the horses and the presence of at least one $B$. caballi-positive horse was expected, as well as the more than $30 \%$ of positive horses on the farm, since it is well known that $D$. nitens is the vector of $B$. caballi in the New World (ROBY; ANTHONY, 1963). Thus, such association can be considered a control of our methods, in order to validate our association analyses between T. equi and ticks. In this context, we found significant association $(\mathrm{P}<0.05)$ of high-level infestation by $A$. cajennense on farms with more than $30 \%$ T. equi-positive horses. This finding was surprising, since one experiment showed that this tick was not a competent vector of T. equi (DENNIG, 1988). Our results showed that high-level infestation by both $A$. cajennense and $D$. nitens was statistically associated $(\mathrm{P}<0.05)$ with the presence of at least one horse positive for T. equi on the farm, although such association for $D$. nitens was not supported by further statistical analyses. In the case of $A$. cajennense, a high level of infestation was statistically associated $(\mathrm{P}<0.05)$ with more than $30 \%$ of horses positive for T. equi on the farms (Table 4).

Guimarães et al. (1998) showed, under experimental conditions, that $R$. (B.) microplus was susceptible to infection by T. equi and was able to transmit it to horses. This finding was later confirmed by other workers (STILLER et al., 2002; UETI et al., 2005; 2008). Cattle are the primary host for $R$. (B.) microplus and it is well known that infestation with this tick on other host species (e.g., horses) is dependent on the presence of cattle in the same area (LABRUNA et al., 2001). In fact, horse infestation by $R$. (B.) microplus has always been reported from an area where cattle have been grazing (BITTENCOURT et al., 1990; HEUCHERT et al., 1999; LABRUNA et al., 2001). During the present study, information about the presence of cattle and their contact with horses was obtained and reported by Labruna et al. (2001), who found at least nine farms on which there were no cattle, either in the farm area or in adjacent areas, nor any $R$. (B.) microplus on the horses. However, at least one horse positive for T. equi by CFT occurred on each of these farms (data not shown). Moreover, two of these farms had more than $30 \%$ of the horses positive for T. equi by CFT. Similar conditions were found on seven farms, using the cELISA results. They did not have any cattle or $R$. (B.) microplus on the horses but had at least one horse positive for T. equi by cELISA. On one of these farms more than $30 \%$ of the horses were positive for T. equi (data not shown). Even though $R$. (B.) microplus could transmit T. equi under natural conditions in Brazil, our findings suggest that other transmission possibilities might exist. The high statistical association $(\mathrm{P}<0.05)$ between the abundance of $A$. cajennense on horses and the presence of more than $30 \%$ of horses positive for T. equi suggests that $A$. cajennense could be acting as a vector of T. equi under natural conditions. This epidemiological indication is reinforced by the fact that all serum samples examined were from young horses (6-24 months old) that had never left the farm area for any reason, and had never received blood transfusions or plasma therapy at any stage of their lives. In addition, all farms having no cattle reported the complete absence of any cattle on the farm for at least 36 months (data not shown), which was a larger period than the maximal age (24 months) of the tested horses. Thus, we can also state that there was no $R$. (B.) microplus established on the farm since the 6-24 month age group was born.

We are aware of the fact that the serologically positive horses detected in the present study became infected before the moment at which we collected their ticks and serum samples. However, we assumed that farms with $A$. cajennense infesting horses had this tick already established in the farm for at least one year because this tick completes only one generation per year in the state of São Paulo (LABRUNA et al., 2002). This statement is especially valid for those farms where we detected high infestation levels of A. cajennense on horses.

Excluding ticks as vectors, other possibilities for these horses to become infected with T. equi could include mechanical transmission or congenital infection. Mechanical transmission was minimized by the fact that all farms reported using only sterile disposable needles for any kind of therapy on the horses. Mechanical transmission of T. equi by biting flies has not been previously reported (FRIEDHOFF, 1988) and in this study, high infestations of horse flies during the summer-spring months were reported on all farms, even those where all the young horses were serologically negative for T. equi.

Intra-uterine infection of foals with $T$. equi has been reported. Some studies report that these foals are usually stillborn, showing the lesions characteristic of equine piroplasmosis, or that infected foals born alive show clinical signs of the disease, which is invariably fatal (ERBSLÖH, 1975; MAIA et al., 2006). Other studies have shown that fetuses may become infected with $T$. equi without developing disease and are born as carriers of the parasite (LEWIS, 1998; ALLSOPP et al., 2007). While it has been argued that transplacental transmission of T. equi within a herd seems to be much more significant than previously thought (ALLSOPP et al., 2007), this is still a controversial issue (KUMAR et al., 2008). Nonetheless, transplacental transmission has not affected our results because it is very unlikely that this kind of transmission would coincidently occur more frequently in farms with highlevel infestation by $A$. cajennense, and where more than $30 \%$ of the horses were infected by $T$. equi.

To date, $R$. (B.) microplus is the only tick species of the Brazilian fauna proven experimentally to transmit T. equi to horses; however, its role in the epidemiology of equine piroplasmosis should be evaluated under field conditions. Since $R$. (B.) microplus is a one-host tick and there is no transovarial transmission of T. equi in ticks (UETI et al., 2008), the only possible transmission of $T$. equi by this tick is by accidental transference of recently molted ticks or by males wandering from horse to horse. Mason and Norval (1981) showed that 69 feeding larvae and two adult males of $R$. (B.) microplus were able to transfer from one bovine (initially infested with 30,000 unfed larvae) to another under a high stocking rate of four cattle per 0.7 ha. Further studies should evaluate transfer rates of $R$. (B.) microplus ticks among horses under field conditions, which would have important implications in the transmission of T. equi in horses grazing on cattle pastures. Our epidemiological findings showing a significant association between T. equi-positive horses and infestations by $A$. cajennense, even on 
farms where there were no $R$. (B.) microplus and cattle, suggest that other transmission mechanisms exist. Our epidemiological data indicates that $A$. cajennense is associated with $T$. equi infection in horses, in opposition to experimental studies that fail to prove A. cajennense as a competent vector. In fact, after our field study, we tried to infect $A$. cajennense ticks by allowing nymphs to feed on a mare with high T. equi parasitemia $(\approx 70 \%)$, but no tick remained infected after molting to the adult stage (M.B. Labruna, C. Kerber, and M.F.B. Ribeiro, unpublished data). While further studies re-evaluating the biological transmission of Brazilian T. equi strains by A. cajennense are still needed, it is possible that other transmission mechanisms yet to be elucidated have their existence on the farm in coincidence with high levels of infestation by $A$. cajennense, which would explain part of our epidemiological associations. Although this remains unclear, our results indicate that prevention measures of $T$. equi infection in Brazil should be based on the control or elimination of $R$. (B.) microplus and $A$. cajennense infestations on horses. For $R$. (B.) microplus, this can be easily achieved by isolating from cattle. Infestation by $A$. cajennense can be controlled by keeping the pastures uniform and in a clean condition through mowing the entire horse pasture area (and removing the mowed grass) at least once a year, during the spring-summer months (LABRUNA et al., 2001). Successful strategic chemical control has also been achieved (LABRUNA et al. 2004).

\section{Acknowledgments}

We thank L. Kappmeyer for technical support during cELISA procedures, and the veterinarians J.C. Cintra Neto, W. Paloca, C. Araújo, T. Bronhall, and N. Roncati for their valuable assistance during farm visits.

\section{References}

ALLSOPP, M. T.; LEWIS, B. D.; PENZHORN, B. L. Molecular evidence for transplacental transmission of Theileria equi from carrier mares to their apparently healthy foals. Veterinary Parasitology, v. 148, n. 2, p. 130-136, 2007.

BALDANI, C. D. et al. An enzyme-linked immunosorbent assay for the detection of IgG antibodies against Babesia equi in horses. Ciência Rural, v. 34, n. 5, p. 1525-1529, 2004.

BALDANI, C. D. et al. Serodiagnosis of Babesia equi in horses submitted to exercise stress. Pesquisa Veterinaria Brasileira, v. 27, n. 4, p. $179-183$.

BALDANI, C. D. et al. In vitro culture, PCR, nested-PCR for the detection of Theileria equi in horses submitted to exercise. Arquivo Brasileiro de Medicina Veterinária e Zootecnia, v. 60, n. 3, p. 550-558, 2008.

BARBOSA, I. P. et al. Epidemiological aspects of equine babesiosis in a herd of horses in Brazil. Veterinary Parasitology, v. 58, p. 1-8, 1995.

BITTENCOURT, A. J. et al. Comportamento do Boophilus microplus (Canestrini, 1887) (Acari) em infestações artificiais e naturais em diferentes hospedeiros. Arquivos da Universidade Federal Rural do Rio de Janeiro, v. 13, n. 2, p. 173-182, 1990.
BITTENCOURT, A. J.; MASSARD, C. L.; MASSARD, C. A. Aspectos epidemiológicos da babesiose eqüina na microregião fluminense do Grande Rio-Itaguaí, Estado do Rio de Janeiro. Revista Brasileira de Ciêncica Veterinária, v. 4, n. 1, p. 13-17, 1997.

BOTTEON, P. T. et al. Seroprevalencia de Babesia equi en tres diferentes sistemas de crianza de equinos, Rio de Janeiro, Brasil. Parasitologia Latinoamericana, v. 57, n. 3-4, p. 141-145, 2002.

CANOLA, P. A. et al. Estudo comparativo entre técnicas de extração de DNA e realização da reação em cadeia da polimerase (PCR) para o diagnóstico de Theileria equi e Babesia caballi. Ars Veterinaria, v. 23, n. 3, p. 165-171, 2007.

CAMPOS PEREIRA, M. et al. Rhipicephalus (Boophilus) microplus: biologia, controle e resistência. São Paulo: Medvet, 2008. 169 p.

CORREA, W. M.; CORREA, C. N. M.; FANTON, E. B. Aborto por babesiose fetal em equino. Arquivo da Escola de Veterinária da UFMG, v. 30, n. 3, p. 303-305, 1978.

COSTA PEREIRA, M. A. V. et al. Variação da sorotitulaçấo ao teste de fixaçáo de complemento para Babesia equi e Babesia caballi em equinos da região serrana do Rio de Janeiro. Ars Veterinaria, v. 21, n. 3 , p. 338-343, 2005.

DENNIG, F. Erfolglose Versuche zur Übertragung von Babesia equi durch Anocentor nitens und Amblyomma cajennense.Hannover, 1988. 122 f. Thesis - Hannover Scholl of Veterinary Medicine.

DE WAAL, D.T. Distribution, transmission and serodiagnosis of Babesia equi and Babesia caballi in South Africa. Pretoria, 1995. PhD thesis - Faculty of Veterinary Science, University of Pretoria.

DE WAAL, D. T. Equine piroplasmosis. In: OIE Manual of Standards for Diagnostic Tests and Vaccines. 4 ed. Paris: OIE, 2000. p. $558-564$.

ERBSLÖH, J. K. E. Babesiosis in the newborn foal. Journal of Reproduction and Fertility, v. 23, p. 725-726, 1975.

FALCE, H. C. Infestações múltiplas por ixodídeos (Acari: Ixodidae) em bovinos e equídeos no primeiro planalto do Estado do Paraná. Revista do Setor de Ciências Agrárias, v. 8, n. 1, p. 11-13, 1986.

FRIEDHOFF, K. T. Transmission of Babesia. In: RISTIC, M. (Ed). Babesiosis of domestic animals and man. Boca Raton: CRC Press, 1988. p. 23-52.

GUIMARÁES, A. M.; LIMA, J. D.; RIBEIRO, M. F. B. Sporogony and experimental transmission of Babesia equi by Boophilus microplus. Parasitology Research, v. 84, n. 4, p. 323-327, 1998.

HEUCHERT, C. M. S. et al. Seroepidemiologic studies on Babesia equi and Babesia caballi infections in Brazil. Veterinary Parasitology, v. 85, n. 1, p. 1-11, 1999.

HEIM, A. et al. Detection and molecular characterization of Babesia caballi and Theileria equi isolates from endemic areas of Brazil. Parasitology Research, v. 102, n. 1, p. 63-68, 2007.

KAPPMEYER, L. S. et al. Detection of equine antibodies to Babesia caballi recombinant $B$. caballi rhoptry-associated protein 1 in a competitive-inhibition enzyme-linked immunosorbent assay. Journal of Clinical Microbiology, v. 37, n. 7, p. 2285-2290, 1999.

KERBER, C. E.; FERREIRA, F.; PEREIRA, M. C. Control of equine piroplasmosis in Brazil. Onderstepoort Journal of Veterinary Research, v. 66, n. 2, p. 123-127, 1999. 
KNOWLES, D. P. et al. Detection of Equine Antibody to Babesia equi Merozoite proteins by a monoclonal Antibody-Based Competitive Inhibition Enzyme-Linked Immunosorbent Assay. Journal of Clinical Microbiology, v. 29, n. 9, p. 2056-2059, 1991.

KNOWLES, D. P. et al. Antibody to a Recombinant Merozoite Protein Epitope Identifies Horses Infected with Babesia equi. Journal of Clinical Microbiology, v. 30, n. 12, p. 3122-3126, 1992.

KUMAR, S. et al. Passive transfer of Theileria equi antibodies to neonate foals of immune tolerant mares. Veterinary Parasitology, v. 151, n. 1, p. 80-85, 2008.

LABRUNA, M. B. et al. Risk factors to tick infestations and their occurrence on horses in the State of São Paulo, Brazil. Veterinary Parasitology, v. 97, n. 1, p. 1-14, 2001.

LABRUNA, M. B. et al. Seasonal dynamics of ticks (Acari: Ixodidae) on horses in the state of São Paulo, Brazil. Veterinary Parasitology, v. 105 , n. 1, p. 65-72, 2002.

LABRUNA, M. B. et al. Controle estratégico do carrapato Amblyomma cajennense em equinos. Ciência Rural, v. 34, n. 1, p. 195-200, 2004.

LEWIS, B. D. Transplacental transmission of Babesia equi in horses and chemotherapy of small Babesia species. Pretoria, 1998. $\mathrm{PhD}$ thesis - University of Pretoria.

MAIA, L.; SOUZA, M. V.; SALCEDO, J. H. P. Babesiose equina em potro neonato. Revista Brasileira de Ciência Veterinária, v. 13, n. 1, p. 63-64, 2006.

MASON, C. A.; NORVAL, R. A. I. The transfer of Boophilus microplus (Acarina: Ixodidae) from infested to uninfested cattle under field conditions. Veterinary Parasitology, v. 8, n. 2, p. 185-188, 1981.

OFFICE INTERNATIONAL DES EPIZOOTIES. Manual of Diagnostic Tests and Vaccines for Terrestrial Animals. Equine Piroplasmosis (updated in 20/12/2005). Disponível em: <http://www. oie.int/eng/normes/mmanual/A_00084.htm>. Acesso em: Apr. 2009.

OGUNREMI, O. et al. Validation of the indirect fluorescent antibody and the complement fixation tests for the diagnosis of Theileria equi. Veterinary Parasitology, v. 148, n. 2, p. 102-108, 2007.

RIBEIRO, M. F. B.; SAITO, J. F.; PIMENTEL, P. V. Babesiose equine. I. Primo-infecção de potros em area endêmica. Arquivo Brasileiro de Medicina Veterinária e Zootecnia, v. 47, n. 5, p. 641-647, 1995.
RIBEIRO, M. F.; COSTA, J. O.; GUIMARÁES, A. M. Epidemiological aspects of Babesia equi in horses in Minas Gerais, Brazil. Veterinary Research Communications, v. 23, n. 6, p.385-390, 1999.

ROBY, T. O.; ANTHONY, D. W. Transmission of equine piroplasmosis by Dermacentor nitens. Journal of the American Veterinary Medical Association, v. 142, n. 7, p. 768-769, 1963.

SOUZA, A. P. et al. Prevalência de anticorpos anti-Babesia equi em equinos no planalto catarinense. Ciência Rural, v. 30, n. 1, p. 119-121, 2000.

SPSS for Windows. SPSS Base 9.0.1. Users guide. Chicago, USA: SPSS Inc., 1999.

STILLER, D.; COAN, M. E. Recent development in elucidating tick vector relationships for anaplasmosis and equine piroplasmosis. Veterinary Parasitology, v. 57, n. 1-3, p. 97-108, 1995.

STILLER, D. et al. Dermacentor variabilis and Boophilus microplus (Acari: Ixodidae): experimental vectors of Babesia equi to equids. Journal of Medical Entomology, v. 39, n. 4, p. 667-670, 2002.

TENTER, A. M.; FRIEDHOFF, K. T. Serodiagnosis of experimental and natural Babesia equi and Babesia caballi infections. Veterinary Parasitology, v. 20, n. 1-3, p. 49-61, 1986.

THRUSFIELD, M. Veterinary Epidemiology. Cambridge: Blackwell Science, 1995. 479 p.

UETI, M. W. et al. Ability of the vector tick Boophilus microplus to acquire and transmit Babesia equi following feeding on chronically infected horses with low-level parasitemia. Journal of Clinical Microbiology, v. 43, n. 8, p. 3755-3759, 2005.

UETI, M. W. et al. Persistently infected horses are reservoirs for intrastadial tick-borne transmission of the apicomplexan parasite Babesia equi. Infection and Immunity, v. 76, n. 8, p. 3525-3529, 2008.

USDA. Animal and Plant Health Inspection Services. Complement fixation test for detection of antibodies to Babesia caballi and Babesia equi - microtitration test. Ames: National Veterinary Services Laboratories, 1997. 27 p.

XUAN, X. et al. Diagnosis of equine piroplasmosis in Brazil by serodiagnostic methods with recombinant antigens. Journal of Veterinary Medical Science, v. 63, n. 10, p. 1159-1160, 2001. 